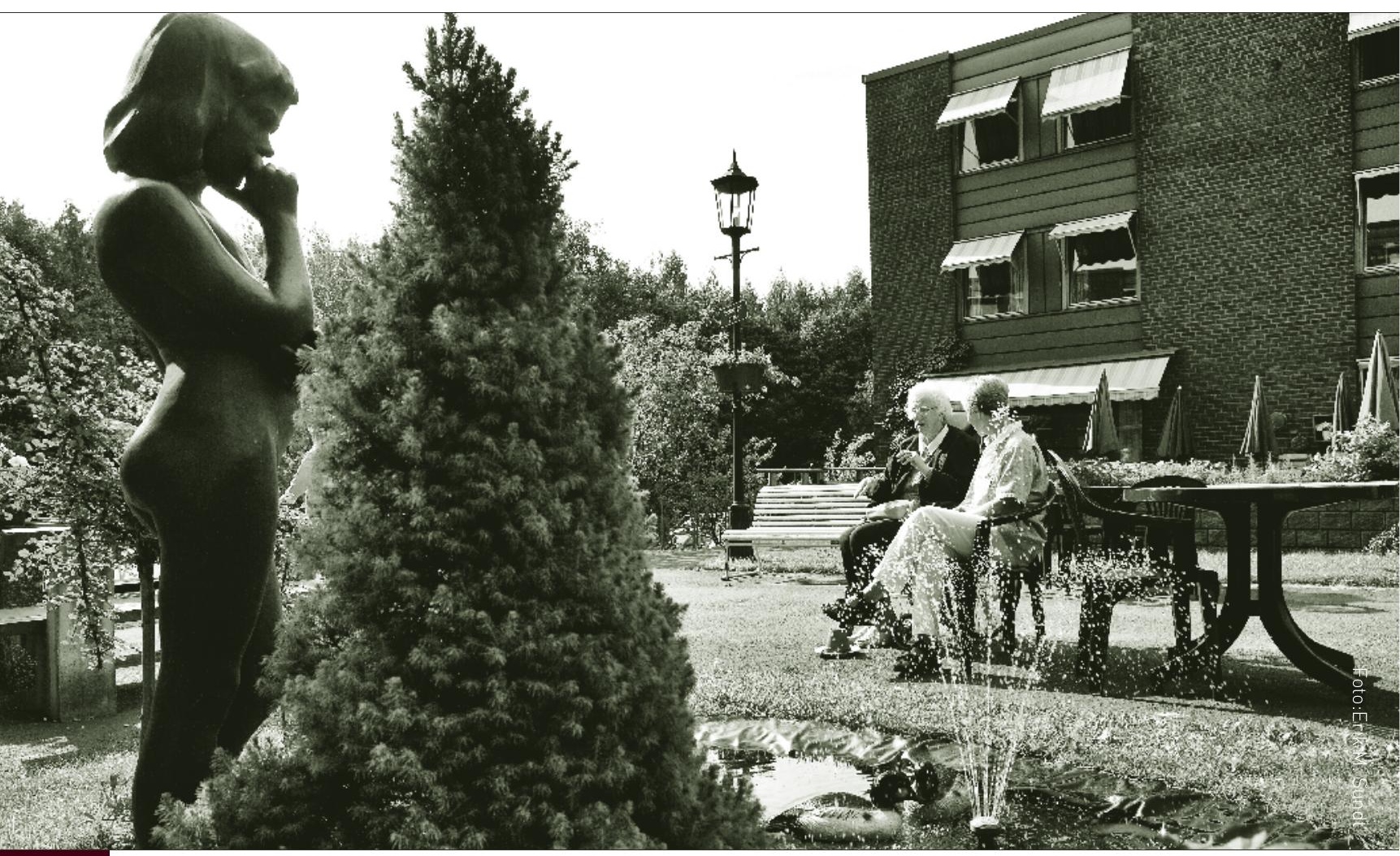

Bakgrunn: Opprettholdelse av god livskvalitet er et viktig mål i demensomsorgen. Miljøbehandling, inklusive sansehager og målrettet bruk av planter brukes i økt grad, men effekten er usikker.

Hensikt: Undersøke og beskrive hva forskningslitteraturen rapporterer på bruk av sansehager, terapeutisk hagebruk og målrettet bruk av planter innendørs for personer med demens.
Metode: Modifisert scoping review med søk i databasene AMED, Cinahl, Medline, ISI Web of Science, Embase, SCOPUS, og SveMed+. Analyse av utvalgte empiriske studier.

Resultat: Femten studier ble inkludert. Ni undersøkte effekt av sansehage, fem terapeutisk hagebruk, en målrettet bruk av planter innendørs. Funnene tyder på at denne typen miljøbehandling kan redusere urolig atferd, bruk av psykofarmaka, alvorlige fall, gi bedre søvn og øke trivsel og funksjonsnivå.

Konklusjon: Sansehage, terapeutisk hagebruk og målrettet bruk av planter innendørs kan ha positiv innvirkning på funksjonsnivå, atferd og trivsel hos personer med demens. Mer forskning er nødvendig.
The importance of sensory garden and therapeutic horticulture in dementia care - a scoping review. Background: Maintaining quality of life is important in dementia care. Sensory gardens and plants are increasingly used, but their effect is uncertain.

Objective: Examine and describe what is reported in the research literature about use of sensory gardens, therapeutic horticulture and the use of indoor plants for people with dementia.
Methods: Modified scoping review with searches in Amed, Cinahl, Medline, ISI Web of Science, Embase, Scopus and SveMed +. In addition, analysis of selected empirical studies.

Results: Fifteen studies were included. Nine examined the effects of sensory gardens, five, horticultural therapy, and one, the use of plants indoors. The findings suggest that this type of environmental management can reduce disruptive behaviour, use of psychotropic drugs and serious falls, in addition to improving sleep and increasing well-being and functional level.

Conclusion: Sensory gardens, therapeutic horticulture and other targeted use of plants may have a positive influence on function, behaviour and well-being among people with dementia. More research is needed.

Keywords: dementia, sensory garden, therapeutic horticulture, environmental management, literature review 


\section{Betydningen av sansehage og terapeutisk hagebruk for personer med demens en scoping review}

Forfattere: Marit Kirkevold og

Marianne Thorsen Gonzalez

\section{NøKKELORD}

- Demens

- Miljø

- Behandling

- Litteraturstudie

\section{INNLEDNING}

Demens er en av de store folkesykdommene som særlig rammer eldre mennesker. Omtrent 70.000 lever med demens i Norge og tallet vil øke betydelig i årene som kommer grunnet økt levealder (1-5). Demens er en samlebetegnelse på en rekke ulike medisinske diagnoser. Over tid fører demens til alvorlig kognitiv svikt, atferdsendringer og stort behov for hjelp (1-5). Tidlig diagnose er viktig for å kunne fjerne underliggende årsaker og iverksette medisinsk behandling der det er mulig (1). Oftest finnes ingen kurativ behandling og de viktigste behandlingsprinsippene er å bevare pasientens evner og funksjoner i så stor grad som mulig, samt fjerne forhold i omgivelsene som forverrer pasientens funksjon, inklusive faktorer som forårsaker stress eller mangel på stimuli $(6,7)$. Opprettholdelse av god livskvalitet er et viktig overordnet mål i demensomsorgen (1-5). Dette er bakgrunnen for at miljøbehandling er sentralt i demensomsorgen (7-9).

\section{SANSEHAGER}

Miljøbehandling vektlegger relasjoner og terapeutiske prosesser i pasientens miljø $(7,8)$ og omfatter tilrettelegging av fysiske, psykiske og sosiale forhold (7-9). Miljøbehandling har som målsetting å bedre funksjonsevnen og øke trivsel, livskvalitet og velvære $(1,7,9$, 10). Et miljøbehandlingstiltak som har fått økende oppmerksomhet i de senere år er bruk av sansehager for personer med demens (9). En sansehage er en tilrettelagt, oftest lukket hage, gjerne plassert i tilknytning til en skjermet enhet for personer med demens hvor pasienter kan oppleve planter og natur, frisk luft og vandre i sikre, tilrettelagte omgivelser (7). Begrepet sansehage refererer til at hagen skal stimulere sansene, særlig syn-, lukte og følesansen. Begrepet «vandrehage» brukes også (11-13), da en viktig hensikt med disse hagene har vært å tilrettelegge for at personer som er urolige skal ha et sikkert og tilrettelagt område å bevege seg i. Videre brukes begrepet «tera-

\section{Hva tilfører artikkelen?}

Studien viser at sansehager synes å ha positiv effekt på livskvaliteten til personer med demens.

\section{Mer om forfatterne:}

Marit Kirkevold er sykepleier og professor. Hun er ansatt ved avdeling for sykepleievitenskap og helsefag-institutt for helse og samfunn, Det medisinske fakultet, Universitetet i Oslo. Marianne Thorsen Gonzalez er psykiatrisk sykepleier, PhD. Hun er ansatt som førsteamanuensis II ved avdeling for sykepleievitenskap og helsefag, Institutt for helse og samfunn, Det medisinske fakultet, Universitetet i Oslo, og som førsteamanuensis ved institutt for sykepleie og helse, Diakonhjemmet høgskole. Kontakt: mtgonzalezamedisin.uio.no. 
peutiske hager» med referanse til at hagen antas å ha terapeutisk effekt på atferdsproblemer og andre helseproblemer, som søvnvansker og nedsatt muskelstyrke (13-15). Bruk av elementer fra naturen som del av miljøbehandling er imidlertid mer omfattende enn det disse begrepene tilsier. I litteraturen omtales også terapeutisk hagebruk (TH) og systematisk bruk av planter innendørs som aktuelle miljøbehandlingstiltak for personer med demens (16).

Det er begrenset forskning på effekten av denne typen «grønn miljøbehandling» for personer med demens. Det meste av forskningen er gjennomført i USA. I Norden er det gjort noen studier i Finland og Sverige. I Norge er det bygget en rekke sansehager for å bedre omsorgen for personer med demens. Det er imidlertid ikke klart hvordan disse hagene brukes og hvilken terapeutisk nytte de har. Hensikten med denne litteraturgjennomgangen er å undersøke og beskrive nøkkelinformasjon fra forskningsfeltet på bruk av sansehage, terapeutisk hagebruk og målrettet bruk av planter innendørs for personer med demens.

\section{METODE}

Det er mange typer review eller litteraturstudier, og det er ingen absolutt enighet om hvilke kjen-

\section{Opprettholdelse av god livskvalitet er et viktig overordnet mål i demensomsorgen.}

19) som metode. Ifølge Arksey og O'Malley (18) er de primære forskjellene mellom en systematisk litteraturstudie og en scoping review, at en scoping review har et mindre avgrenset forskningsspørsmål enn en systematisk litteraturstudie, bruker flere kilder for å identifisere relevante studier, inkluderer studier med ulike design og metoder og avklarer inklusjonskriterier post hoc (etter at søkene er gjennomført). En scoping review har som hensikt å gi en oversikt over et forskningsfelt og gi en deskriptiv presentasjon av nøkkelinformasjon i de inkluderte artiklene. En scoping review vil således ikke omfatte en summering eller syntese av evidens eller gi en kvalitetsvurdering av evidensnivå, slik man gjerne forventer ved en systematisk litteraturstudie eller metaanalyse. Vi har valgt en scoping review som metode, dels fordi forskningsfeltet er begrenset, og at det derfor var hensiktsmessig å inkludere alle relevante studier som innfridde inklusjonskriteriene, og for å gi en presentasjon av forskningsfeltet. Valg av betegnelsen modifisert scoping review er benyttet fordi vi i noe større grad enn ved en ordinær

\section{Atferdsproblemer ble redusert og bruk av «ved behov»-medikamenter falt etter at vandrehagen ble åpnet.}

netegn eller kriterier som ligger til grunn for den enkelte type review. Vi har i denne litteraturgjennomgangen valgt en modifisert scoping review (17- scoping review, har benyttet et systematisk søk i databasene for å identifisere artiklene, en systematisk fremgangsmåte i inkludering av artikler og en systematisk fremgangsmåte i lesing og ekstrahering av informasjon fra artiklene.

Vi har benyttet systematiske søk i mars 2011 i databasene AMED, Cinahl, Medline (Ovid), ISI Web of Knowledge, Embase, SCOPUS, og SveMed+. Søkene ble begrenset til fagfellevurderte publikasjoner på engelsk, norsk, svensk eller dansk. I identifikasjon av artikler ble fritekstordene "healing garden», «horticultural therapy», «restorative garden» og «wander garden» benyttet. Fritekstordene ble deretter kombinert med demens og Alzheimer. Det er ikke søkt eksplisitt i forhold til design, metode eller utfallsmål. To reviewere vurderte artiklene med tanke på kriterier for inklusjon i litteraturstudien. Inklusjonskriteriene som ble benyttet var at artiklene ga en tydelig beskrivelse av sentral nøkkelinformasjon som hensikt og problemstilling, utvalg, design og metode, fremgangsmåte i intervensjonen, utfallsmål og funn. Studier som var mangelfullt beskrevet i forhold til flere av kriteriene ble ekskludert. Søkestrategi kan fås ved å kontakte artikkelforfatterne. Nøkkelinformasjon fra artiklene er synliggjort $\mathrm{i}$ tabell 1.

\section{RESULTAT}

Nittito originale artikler ble gjennomgått ved hjelp av tittel og abstrakt. Femtien av disse ble ekskludert ettersom de enten ikke var forskningsartikler, ikke var rettet mot personer med demenslidelser eller benyttet bruk av sansehage, terapeutisk 
FIGUR 1: Artikkelutvelgelse

Litteratursøk, mars 2011 ( $\mathrm{n}=92$ )

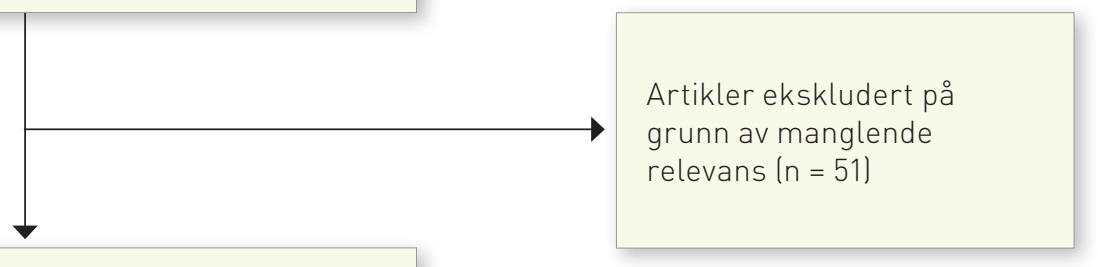

Potensielt relevante artikler vurdert etter tittel og sammendrag ( $n=41)$

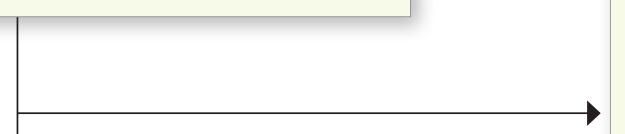

Artikler ekskludert

etter gjennomlesing

i fulltekst ( $n=23$ )

Artikler med relevans for bruk av sansehage for personer med demens ( $n=18$ )

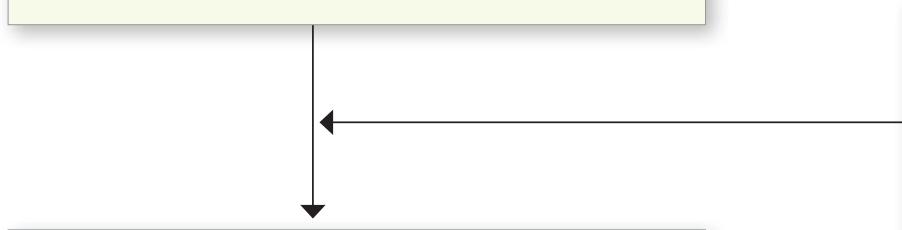

Artikler inkludert fra litteraturlisten til de foreløpig inkluderte artiklene ( $\mathrm{n}=4)$

Artikler i fulltekst vurdert i detalj med tanke på relevans og kriterier for inklusjon ( $n=22$ )

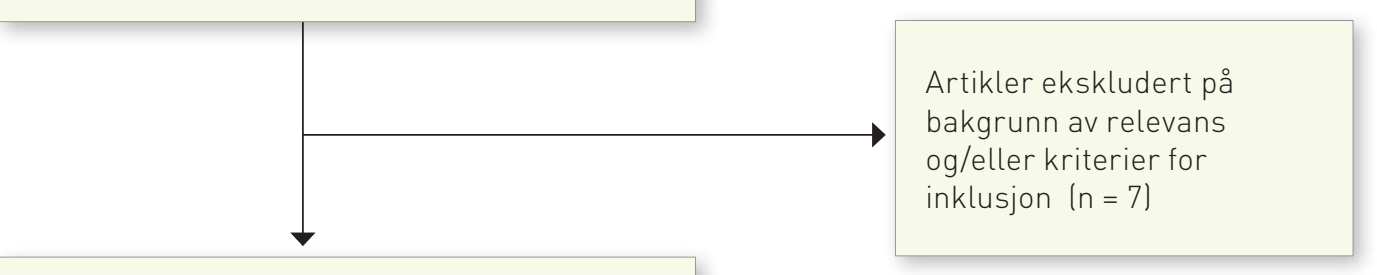

Antall artikler inkludert ( $n=15$ )

hagebruk eller «grønn miljøbehandling». Førtien artikler ble etter første gjennomgang vurdert som potensielt relevante og gjennomgått i fulltekst. Tjuetre av disse ble ekskludert fordi de ikke beskrev en relevant intervensjon, ikke var empiriske studier eller undersøkte personer med demens. Litteraturlistene i det foreløpige utvalget ble gjennomgått og fire potensielt relevante artikler innhentet. Etter en grundig gjennomlesning i fulltekst med tanke på endelig 
TABELL 1: Tabell over inkluderte studier - nøkkelinformasjon

\begin{tabular}{|c|c|c|c|c|}
\hline $\begin{array}{l}\text { Studie } \\
\text { (Forfatter, år, } \\
\text { land, ref.nr.) }\end{array}$ & Hensikt & Studiedesign & Utvalg & Intervensjon \\
\hline $\begin{array}{l}\text { Connell, } \\
\text { Sanford, } \\
\text { Lewis, } \\
2007 \text { (31) }\end{array}$ & $\begin{array}{l}\text { Undersøke effek- } \\
\text { ten av et utendørs } \\
\text { aktivitetsprogram, } \\
\text { sammenliknet } \\
\text { med et innendørs } \\
\text { aktivitetesprgram, } \\
\text { på søvn og atferd } \\
\text { blant sykehjems- } \\
\text { beboere. }\end{array}$ & $\begin{array}{l}\text { Sammenliknende design } \\
\text { med målingspunkter } \\
\text { ved baseline og under } \\
\text { intervensjonen. Ett års } \\
\text { pilotstudie. }\end{array}$ & $\begin{array}{l}\text { Beboere i sykehjem } \\
(\mathrm{N}=20)(19 \text { menn), } \\
79,7 \mathrm{a} \text { ( } 64-90), 5 \\
\text { afroamerikanske, } \\
15 \text { hvite. }\end{array}$ & $\begin{array}{l}\text { Deltakerne ble randomisert til } \\
\text { strukturert aktivitetsprogram } \\
\text { innendørs (m/hortikulturfokus) eller } \\
\text { utendørs (dagslys og strukturerte } \\
\text { hageaktiviteter), i gruppe på 4-6 } \\
\text { personer. }\end{array}$ \\
\hline $\begin{array}{l}\text { Calkins, } \\
\text { Szmere- } \\
\text { kovsky, Biddle, } \\
2007(24)\end{array}$ & $\begin{array}{l}\text { Unders } \varnothing \text { ke om } \varnothing \mathrm{kt} \\
\text { tid utendørs har } \\
\text { betydning for søvn } \\
\text { og agitert atferd. }\end{array}$ & $\begin{array}{l}\text { Før og etter kvasi- } \\
\text { eksperimentelt design } \\
\text { med gjentatte målinger. }\end{array}$ & $\begin{array}{l}\text { Beboere på } 3 \text { syke- } \\
\text { hjem (N=17), } \\
15 \text { kvinner. } \\
15 \text { var hvite, } \\
1 \text { afroamerikansk } \\
\text { og } 1 \text { hispanic. }\end{array}$ & $\begin{array}{l}\text { Utendørsaktivitet } 30 \text { min. daglig. } \\
\text { Deltakerne var sine egne kontroller } \\
\text { og ble observert vinter og sommer } \\
\text { med og uten aktivitet utendørs. Uten } \\
\text { aktivitet var observasjonstid } 1 \text { uke, } \\
\text { med aktivitet var observasjonstid } \\
2 \text { uker. }\end{array}$ \\
\hline $\begin{array}{l}\text { Rappe \& Topo, } \\
2007 \text { (Finland) } \\
\text { (23) }\end{array}$ & $\begin{array}{l}\text { Etablere betydnin- } \\
\text { gen av planter } \\
\text { for velvære hos } \\
\text { finske eldre med } \\
\text { demens. }\end{array}$ & $\begin{array}{l}\text { Study 1: Survey med luk- } \\
\text { kede og ånne spørsmål } \\
\text { Study 2: Observasjons- } \\
\text { studie. }\end{array}$ & $\begin{array}{l}\text { Study 1: Personale } \\
(\mathrm{N}=65) \text {. } \\
\text { Study 2: Pasienter } \\
\text { med demens i } 8 \\
\text { demensenheter } \\
(\mathrm{N}=123) \text {. }\end{array}$ & Ingen. \\
\hline $\begin{array}{l}\text { Gigliotti, } \\
\text { Jarrott, } \\
2005(28)\end{array}$ & $\begin{array}{l}\text { Undersøke om } \\
\text { hagerelaterte } \\
\text { aktiviteter mer } \\
\text { enn ordinære } \\
\text { aktiviteter: Øker } \\
\text { nivået av engasje- } \\
\text { ment. Reduserer } \\
\text { nivået av ikke- } \\
\text { engasjement. } \\
\emptyset \text { ker positive } \\
\text { affekter. }\end{array}$ & $\begin{array}{l}\text { Sammenliknende } \\
\text { studie med før og etter } \\
\text { design. Observasjons- } \\
\text { studie. Intervju med } 7 \\
\text { spørsmål. }\end{array}$ & $\begin{array}{l}\text { Demente brukere av } \\
\text { et dagsenter ( } N=48) \text {, } \\
26 \text { menn og } 22 \text { kvin- } \\
\text { ner. } \\
\text { Gj.snittsalder } 80 \\
\text { (46-98). } \\
41 \text { hvite og } 7 \text { svarte. }\end{array}$ & $\begin{array}{l}\text { Hagerelaterte aktiviteter ble tilret- } \\
\text { telagt } 1 / 2 \text { time per uke over } 9 \text { uker } i \\
\text { tillegg til ordinære ADS aktiviteter }\end{array}$ \\
\hline $\begin{array}{l}\text { Gigliotti, } \\
\text { Jarrott, } \\
\text { Yorgason, } \\
2004 \text { (29) }\end{array}$ & $\begin{array}{l}\text { Å undersøke } \\
\text { utbytte og nytte } \\
\text { av hagerelaterte } \\
\text { aktiviteter på et } \\
\text { dagsenter for } \\
\text { voksne demente. }\end{array}$ & $\begin{array}{l}\text { Explorativt før og etter } \\
\text { design med deltakerne } \\
\text { som sine egne kontrol- } \\
\text { ler. Observasjons- } \\
\text { studie. }\end{array}$ & $\begin{array}{l}\text { Eldre demente ( } \mathrm{N}=14 \text { ) } \\
\text { som deltok i mer enn } \\
5 \text { av } 26 \text { HT aktiviteter. } \\
\text { Gj.snitt. MMSE=16.7 } \\
\text { (2-27). }\end{array}$ & $\begin{array}{l}\text { HT aktiviteter i } 30 \text { min., } 3 x p e r \text { uke } \\
\text { over } 9 \text { uker i gruppe både inne og ute. }\end{array}$ \\
\hline $\begin{array}{l}\text { Cox, Burns, } \\
\text { Savage, } \\
2004 \\
\text { (21) }\end{array}$ & $\begin{array}{l}\text { Undersøke og } \\
\text { sammenlikne } \\
\text { nytten av to typer } \\
\text { sansemiljøer } \\
\text { (Snoezelen room } \\
\text { vs. sansehage) } \\
\text { hos personer } \\
\text { med demens. } \\
\text { Undersøke nyt- } \\
\text { ten/responsen } \\
\text { hos personale og } \\
\text { besøkende. }\end{array}$ & $\begin{array}{l}\text { Sammenliknende studie } \\
\text { med innen gruppe } \\
\text { cross-over design. } \\
\text { Studie 1: Kvantitativ } \\
\text { observasjonsstudie av } \\
\text { demente. Studie 2: } \\
\text { Kvalitativ studie: Ansikt } \\
\text { til ansikt intervju av per- } \\
\text { sonale og besøkende. }\end{array}$ & $\begin{array}{l}\text { Demente på } 3 \text { ulike } \\
\text { kognitive nivå }(N=24), \\
23 \text { kvinner. } \\
\text { Personale } \\
(\mathrm{N}=6) \text {. } \\
\text { Besøkende }(\mathrm{N}=6) .\end{array}$ & $\begin{array}{l}\text { Studie 1: } 3 \text { individuelle sesjoner à } \\
16 \text { min i } 3 \text { omganger ( } 9 \text { sesjoner per } \\
\text { beboer). } \\
\text { Studie 2: Ikke intervensjonsstudie }\end{array}$ \\
\hline $\begin{array}{l}\text { Mather, } \\
\text { Nemecek, } \\
\text { Oliver, } 1997 \\
\text { (25) }\end{array}$ & $\begin{array}{l}\text { Undersøke om } \\
\text { en inngjerdet } \\
\text { hage kan bidra til } \\
\text { atferdsendring } \\
\text { ved Alzheimer. }\end{array}$ & $\begin{array}{l}\text { Sammenliknende, } \\
\text { observasjonsstudie med } \\
3 \text { observasjonspunkter } \\
\text { (pre-test, mid-test, } \\
\text { post-test). }\end{array}$ & $\begin{array}{l}\text { Eldre beboere med } \\
\text { Alzheimer }(N=10), 3 \\
\text { menn. Gj.snittsalder } \\
83(69-100) .\end{array}$ & $\begin{array}{l}\text { Intervensjonsstudie med kartleg- } \\
\text { ging av adferdskategorier utendørs } \\
\text { og innendørs etter innføring av } \\
\text { inngjerdet hage. }\end{array}$ \\
\hline
\end{tabular}




Utfallsmål
1. Søvnstatus (kl. 19.00-07.00) 10 dager
v/baseline og 10 dager intervensjon ble
målt m/håndleddsaktigraf (fotocelle).
2. Frekvens av oppvåkning, max søvnlengde
og totalt søvnmengde ble målt.
3. Adferd ble målt vha Cohen-Mansfield
Agitation Inventory (CMAl).

1. Søvn: Actilume-L og Pittsburg Sleep Quality Index (PSQI).

2. Atferd: Cohen-Mansfield Agitation. Inventory Short Form (CMAl).

3. Actiwatch.

\section{Hovedfunn}

De to gruppene hadde samme lyspåvirkning ved baseline. Utendørsgruppen hadde vesentlig mer lyspåvirkning ila intervensjonen enn innendørsgruppen. I løpet av intervensjonsperioden bedret $\varsigma \varnothing v n e n$ seg signifikant $i$ utendørsgruppen på to av tre mål. Gjennomsnittlig max søvnlengde økte med en time og total søvnmengde med ca 50 minutter. I innendørsgruppen $\varnothing k t e$ total søvnmengde med ca. 60 minutter. Maksimum søvnlengde endret seg også, men ikke statistisk signifikant. Verbal agitasjon endret seg signifikant i utendørsgruppen. Ingen øvrige endringer i adferd.

$\emptyset k t$ tid utendørs gir en moderat bedring i søvn, men ikke målbare endringer i agitasjon.
Study 1: 1. Personalets observasjoner av demente eldre.

Study 2: 1. Dementia Care Mapping (DCM).
Study 1: Planter forbedret det fysiske miljøet og bidro til psykologisk velvære og sosiale relasjoner.

Study 2: A være utendørs stimulerte sansene, og ga kontinuitet til livslange vaner.
1. Kognitivt funksjonsnivå: Minimal Mental Status Examination (MMSE).

2. Adferd: Kodede kategorier.

3. Sosiale, hagereleterte, produktive og ingenting.

4. Affect: Dementia Care Mapping (DCM).
Signifikant forskjell i gjennomsnittlig tidsbruk mellom HT (78\%) og ADS $(28 \%)$.

Signifikant forskjell i ikke engasjert tidsbruk mellom HT (14\%) og ADS (60\%). Signifikant høyere positive affekt ved HT.

MMSE var positivt assosiert med uttrykt affekt under HT.
1. Kognitivt funksjonsnivå: MMSE.

2. Atferd: Kodede kategorier: Sosiale, hagereleterte, produktive og ingenting. 3. Affekt: DCM.

Studie 1: 1.Affekter: Affect Rating Scale (ARS).

Ingen signifikante forskjeller mellom de forskjellige aktivitetene i affekter eller \% tid benyttet. Høyere affekt og adferd ved HT enn ved normale aktiviteter. Lavere nivåer av ikke-engasjement ved HT enn ved normale aktiviteter. Gj. snitt affekt score var sign. høyere ved HT enn ved normale aktivteter. MMSE score var korrelert med nivå av affekt og \% av tid benyttet i HT. MMSE var ikke sign. korrelert med score på utfallsmål.

Studie 1:Ingen konsistent forskjell mellom de fire målingene som ble gjort innen samme miljø. Ingen sign. funn knyttet til utfallsmål knyttet til samme miljø. Det var gjennomgående positive affektnivåer. Signifikant mer rapportert tristhet i dagligstue enn de to sanserommene. De som var på de høyeste kognitive nivåene tenderte til å score høyere på tilfredshet/glede enn de på lavere kognitive nivåer.

Studie 2: Nye miljøer så ut til å aktivere mer positive følelser hos beboerne. Hagen engasjerte og aktiverte. Snoezelen roet og virket avslappende.

1. Atferd: Observasjoner av atferdskategorier med Baumgarten, Becker and Gauthier's checklist. Hver deltaker ble vurdert for 22 adferdskategorier. Utendørs om sommeren var det gjennomsnittlig observasjonstid 30 timer pr. måned over 3 måneder. Innendørs var det 32 timer observasjonstid om sommeren og 34 timer om vinteren.
Ingen forskjeller i urolig (disruptive) atferd på ulike døgnskift i ulike sommerperioder. Utendørs observasjoner: Beboerne tilbrakte $14 \%$ av tiden utendørs i hagen. $54 \%$ av tiden ute ble benyttet til å sitte og evt. snakke. $26 \%$ av tiden ble benyttet til gåing. $7 \%$ av tiden til soving og $7 \%$ i aktiv sosial kontakt med andre. Sammenliknet med innendørs observasjoner: De som hadde størst endringer i atferd var de som benyttet hagen mest. Soving om ettermiddagen, vandring, og kikke ut av vinduet var hyppigere på vinteren enn om sommeren. 


\begin{tabular}{|c|c|c|c|c|}
\hline $\begin{array}{l}\text { Studie } \\
\text { (Forfatter, } \\
\text { år, land, } \\
\text { ref.nr.) }\end{array}$ & Hensikt & Studiedesign & Utvalg & Intervensjon \\
\hline $\begin{array}{l}\text { Murphy m. } \\
\text { fl., 2010* } \\
\text { (USA) (11) }\end{array}$ & $\begin{array}{l}\text { Undersøke } \\
\text { sammenheng } \\
\text { mellom besøk i } \\
\text { vandrehage og } \\
\text { agitasjon. }\end{array}$ & $\begin{array}{l}\text { Før og etter } \\
\text { design. Obser- } \\
\text { vasjonsstudie } \\
1 \text { år ør og } 1 \text { år } \\
\text { etter etablering av } \\
\text { vandrehage. }\end{array}$ & $\begin{array}{l}\text { Pasienter med } \\
\text { demens i demensen- } \\
\text { het (N=34). } \\
\text { Mellom } 74 \text { og } 92 \text { år } \\
\text { lgjennomsnitt } 80.7 \\
\text { àr). Alle menn. }\end{array}$ & $\begin{array}{l}\text { Åpnet vandrehage som var fritt tilgjengelig for } \\
\text { beboerne i demensenheten. }\end{array}$ \\
\hline $\begin{array}{l}\text { Jarrot \& } \\
\text { Gigliotti } \\
2010 \\
\text { (USA) } \\
\text { (27) }\end{array}$ & $\begin{array}{l}\text { Undersøke om } \\
\text { hagerelaterte } \\
\text { aktiviteter mer } \\
\text { enn ordinære } \\
\text { aktiviteter øker } \\
\text { nivået av adaptiv } \\
\text { atferd og positiv } \\
\text { affekt. }\end{array}$ & $\begin{array}{l}\text { Sammenliknende } \\
\text { observasjons- } \\
\text { studie med cluster } \\
\text { randomisering. } \\
\text { Omsorgspro- } \\
\text { grammene ble } \\
\text { randomisert, men } \\
\text { ikke deltakerne. }\end{array}$ & $\begin{array}{l}\text { Demente i } 8 \text { forskjel- } \\
\text { lige omsorgspro- } \\
\text { grammer ( } \mathrm{N}=129 \text { ) } \\
75 \text { i HT gruppen } \\
54 \text { i TA gruppen (HT } \\
\text { gruppen var gjen- } \\
\text { nomsnittlig eldre enn } \\
\text { TA gruppen). }\end{array}$ & $\begin{array}{l}\text { Deltakelse i HT (hageaktivitet)eller TA lordinær } \\
\text { aktivitet) min } 50 \% \text { av observasjonstiden ( } 50 \\
\text { min.). } \\
\text { Grupper på } 4-20 \text { pas. med max størrelse på } 8 \\
\text { pas. }\end{array}$ \\
\hline $\begin{array}{l}\text { Detweiler } \\
\text { m.fl., } \\
2009 * \\
\text { (USA) (12) }\end{array}$ & $\begin{array}{l}\text { Undersøke } \\
\text { sammenheng } \\
\text { mellom besøk } \\
\text { i vandrehage } \\
\text { og frekvens og } \\
\text { alvorlighetsgrad } \\
\text { av fall, samt bruk } \\
\text { av medikamenter. }\end{array}$ & $\begin{array}{l}\text { Sammenliknende } \\
\text { studie med før } \\
\text { og etter design. } \\
\text { Observasjoner } \\
1 \text { år før og } 1 \text { år } \\
\text { etter etablering av } \\
\text { vandrehage. }\end{array}$ & $\begin{array}{l}\text { Pasienter med } \\
\text { demens (alle menn) } \\
\text { i demens-enhet } \\
\text { (N=28). Alder mellom } \\
74 \text { og } 92 \text { år (gjennom- } \\
\text { snitt } 80,5 \text { år). } \\
\text { Inndelt i } 2 \text { grupper }\end{array}$ & $\begin{array}{l}\text { Apnet vandrehage som var fritt tilgjengelig for } \\
\text { beboerne i demensenheten. }\end{array}$ \\
\hline $\begin{array}{l}\text { Thelander } \\
\text { m.fl., } \\
2008 \\
\text { (Sverige) } \\
\text { (30) }\end{array}$ & $\begin{array}{l}\text { Evaluere om } \\
\text { hageaktiviteter } \\
\text { i utendørsomgi- } \\
\text { velser kan være } \\
\text { en integrert del } \\
\text { av rehabilitering } \\
\text { og omsorg for } \\
\text { personer med } \\
\text { demens. }\end{array}$ & $\begin{array}{l}\text { Før og etter } \\
\text { design. }\end{array}$ & $\begin{array}{l}\text { Sykehjemsbeboere } \\
\text { ( } N=8 \text { ) med alvorlig } \\
\text { til moderat demens } \\
\text { (MMSE 5-18), agita- } \\
\text { sjon og uro, interesse } \\
\text { i utendørsaktiviteter. } \\
\text { Ikke rullestolbrukere } \\
\text { og personer som ikke } \\
\text { tålte fysisk aktivitet. }\end{array}$ & $\begin{array}{l}\text { Individualiserte hageaktiviteter og gange i nær- } \\
\text { liggende park, } 3 \text { x per uke i } 6 \text { uker (sommertid). }\end{array}$ \\
\hline $\begin{array}{l}\text { Lee \& } \\
\text { Kim, 2008 } \\
\text { (Korea) } \\
\text { (32) }\end{array}$ & $\begin{array}{l}\text { Undersøke nyt- } \\
\text { ten av innendørs } \\
\text { hagearbeid på } \\
\text { søvn, agitasjon } \\
\text { og kognisjon } \\
\text { blant personer } \\
\text { med demens. }\end{array}$ & $\begin{array}{l}\text { Før og etter design } \\
\text { med repeterte } \\
\text { måle punkter. }\end{array}$ & $\begin{array}{l}\text { Sykehjemsbeboere } \\
\text { ( } N=23) \text { med mild til } \\
\text { moderat demens, } \\
\text { søvnforstyrrelser, og/ } \\
\text { eller agitasjon. }\end{array}$ & $\begin{array}{l}\text { Innendørs vannbaserte hageaktiviteter av spise- } \\
\text { lige vekster (bønneskudd og kinesisk selleri) ble } \\
\text { valgt pga gjenkjennelighet, enkelhet, rask vekst } \\
\text { etc. } 1 \text { ukes baseline registrering, } 4 \text { ukers inter- } \\
\text { vensjon. Hver deltaker valgte foretrukket plante, } \\
\text { dyrket og høstet x } 3-4 \text { ganger i løpet av interven- } \\
\text { sjonen. Pleier assisterte pasienten morgen og } \\
\text { kveld i oppfølging av plantene. Pasient spiste selv } \\
\text { grønnsakene. }\end{array}$ \\
\hline $\begin{array}{l}\text { Grant \& } \\
\text { Wineman, } \\
2007 \\
\text { (USA) (22) }\end{array}$ & $\begin{array}{l}\text { Utvikle «The Gar- } \\
\text { den-Use Model» } \\
\text { - et instrument } \\
\text { for } ø \text { kt bruk } \\
\text { av utendørs- } \\
\text { omgivelsene } \\
\text { blant personer } \\
\text { med demens i } \\
\text { sykehjem. }\end{array}$ & $\begin{array}{l}\text { Multi-case studie } \\
\text { design. }\end{array}$ & Fem sykehjem. & Ingen. \\
\hline $\begin{array}{l}\text { Hernan- } \\
\text { dez } 2007 \\
\text { (USA) } \\
\text { (20) }\end{array}$ & $\begin{array}{l}\text { Undersøke } \\
\text { hvilken betydning } \\
\text { hagedesignet } \\
\text { har på beboer- } \\
\text { nes livskvali- } \\
\text { tet. }\end{array}$ & $\begin{array}{l}\text { Kvalitativ evalu- } \\
\text { eringsstudie med } \\
\text { case studie design } \\
\text { med flere metoder } \\
\text { (intervju, atferds- } \\
\text { kartleggingog } \\
\text { observasjoner). }\end{array}$ & $\begin{array}{l}\text { Hageområdene i } 2 \\
\text { demensenheter i } \\
\text { byområde, hvor det } \\
\text { var lagt på demens- } \\
\text { vennlig design. }\end{array}$ & Ingen. \\
\hline
\end{tabular}

* Rapporterer fra samme studie/materiale 


\section{Utfallsmål}

Hovedfunn

1. Agitasjon, registrert v.h.a. CohenMansfield Agitation Inventory (CMAl) før hagen ble åpnet og månedlig i 12 mnd etter åpningen.
Agitasjon ble redusert mest blant de som brukte hagen mest. For ambulante beboere var også begrenset bruk av hagen forbundet med redusert agitasjon, mens lav bruk blant personer i rullestol/avhengige av hjelp ikke hadde tilsvarende effekt.

Signifikante forskjeller i engasjement i 4 av 5 kategorier knyttet til adaptiv atferd og større prosentvis deltakelse i HT enn TA. TA gruppen var selvengasjert, mens HT gruppen også viste større interesse for andre aktiviteter. Ingen forskjeller i gruppene i affekt. Det var sign. korrelasjon mellom alder og interesse.
Koding av atferdskategorier med

1. Minimal Mental Status Exam (MMSE)

2. Apparent Affect Rating Scale (AARS).

3. Engasjement: Menorah Park Engagement Scale (MPES).

\author{
1. Frekvens av fall. \\ 2. Alvorlighetsgrad av fall (The Fall \\ Severity Score). \\ 3. Kartlegging av medikamentbruk (type \\ og dose - antidepressiva, angstdem- \\ pende, antipsykotika, sovemedisiner).
}

Signifikant reduksjon i fall etter introduksjon av vandrehage $130 \%$ reduksjon i antall og alvorlighetsgrad). Færre alvorlige fall. Størst reduksjon i alvorlige fall for beboere i gruppen som brukte hagen mest. Signifikant reduksjon i bruk av antipsykotika, særlig for de som brukte hagen mest.
1. Type aktiviteter som fungerte og ikke. 2.Grad av uavhengighet i gjennomføring av aktiviteter (1=uavhengig.

$6=$ helt avhengig).

3. Faktorer som påvirket evne til gjennomføring.
Type aktivitet som var mulig og tiltalende for den enkelte varierte betydelig. I gjennomsnitt varierte grad av uavhengighet mellom 2-5 på uavhengighetsskalaen. Halvparten trengte kontinuerlig hjelp (4-6), primært pga fare for å falle. Aktiviteter som de selv igangsatte klarte de å utføre mer uavhengig. Mange av aktivitetene var for vanskelige for deltakerne, grunnet dårlig fysisk funksjon (balanse, styrke, nedsatt syn/persepsjon, etc).
Søvn og agitasjon ble kartlagt i en uke før oppstart og dessuten en uke på slutten av intervensjonen.

1. 24-timers søvnlogg ble ført av pleiere daglig i uke 1 og uke 5.

2. Agitasjon ble målt daglig vha CMAl i uke 1 og 7. Kognisjon ble målt 1 gang $i$ uke 1 og i uke 5 vha revised Hasegawa Dementia Scale.

Kartlegging av bruken av utendørsarealene i sykehjemmene:

1. Foreløpig analyse av sykehjemsarealene.

2. Spørreskjema til personalet.

3. Seks dagers observasjon av atferd/ bruk av arealene.

1. Beboere, personale og pårørende ble intervjuet om bruk av hagene. 2 . Observasjon av hvordan hagen ble brukt latferdskartlegging, hvilke områder ble brukt, hvordan ble områdene brukt). 3. Emosjonell reaksjon på hagen vha AARS (Apparent Affect Rating Scale). 4. Kartlegging av negative og positive emosjoner i periode på 5 minutter.
Signifikant bedring i nattesøvn, oppvåkning etter innsovning, soving på dagtid, samt reduksjon i agitasjon og bedret kognisjon. Effekten antas å kunne knyttes til flere faktorer: Bedret kronobiologisk rytme, økt fysisk aktivitet, praktisering av tidligere ferdigheter, hobbier, reminisens, sosial interaksjon, sensorisk stimulering og opplevelse av å ha utrettet noe meningsfullt.

«The Garden-Use Model» er en teoretisk modell som kan gi en strukturert basis for å diskutere faktorer som påvirker bruk av utendørsområdene. Metoden kan brukes for å identifisere forhold som kan øke bruken av utendørsområdene.

Totalt 28 personale, 12 pårørende og 5 arkitekter/designere ble intervjuet. Uformelle samtaler med beboere skjedde spontant ila observasjonsperiodene. Innholdsanalyse identifiserte tre hovedtemaer: 1. Hagen har en terapeutisk effekt psykisk og fysisk 2.Policy/praksis ved sykehjemmene påvirket bruken av hagen. 3. Anbefalinger for å bedre hagen - dvs. gjøre den mer meningsfull og nyttig for beboere, pårørende og personale. Det ble fremhevet at hagen bidro til bedre livskvalitet både gjennom passiv bruk (sitte ute), lavaktivitet lavledning/reduksjon av stress og agitasjon) og ved aktiv bruk (fysisk aktivitet, sosial aktivitet, kulturell aktivitet) og direkte hagebruk. Værforhold og begrenset adgang til hagen reduserte utnyttelsen og effekten. 
inkludering i lys av relevans og kriterier for inkludering, ble ytterligere sju artikler ekskludert. Totalt ble 15 artikler inkludert med tanke på relevans og kriterier for inklusjon. Figur 1 sammenfatter artikkelutvelgelsen.

Studienes utvalg er begrenset, antall inkluderte pasienter i studiene varierer fra åtte til 129. Til sammen inkluderer studiene 450 pasienter. Forskningsdesign varierer fra casestudier $(\mathrm{n}=2)$, kartleggingsstudie $(\mathrm{n}=1)$, intervensjonsstudier med ulike pretest-posttest design $(\mathrm{n}=10)$ til randomiserte kontrollerte studier (RCT) $(n=2)$. Casestudiene tilfører litteraturgjennomgangen innsikt $i$ hvordan sansehager og terapeutisk hagebruk kan gjennomføres og ha positiv innvirkning på individnivå. De kontrollerte studiene tilfører innsikt $\mathrm{i}$ intervensjonens effekt på gruppenivå. Vi anser det som viktig å inkludere begge nivåene i litteraturgjennomgangen. Anerkjente standardiserte og validerte utfallsmål ble benyttet i de fleste studiene. Nesten alle refererte til teoretisk ram-
$\mathrm{Ni}$ av artiklene omhandlet "passiv bruk» av sansehager (11-13, 20-25). Tre artikler (1113) rapporterer fra forskjellige utfallsmål fra samme observasjonsstudie med et før- og etterdesign gjennomført ved en institusjon for veteraner i USA. En artikkel (11) rapporterer en signifikant nytteverdi på atferd blant dem som spontant brukte hagen mest og de som uavhengig kunne bruke hagen. De som brukte hagen lite eller var avhengige av hjelp for å komme seg ut hadde derimot ikke tilsvarende nytteverdi. I en annen artikkel (12) rapporteres en reduksjon på 30 prosent $\mathrm{i}$ antall fall og i alvorlige fall relatert til kategorisering av fall etter et standardisert utfallsmål. Ved å dele brukerne $i$ to grupper (storbrukere og småbrukere) fant forskerne at de brukerne som benyttet hagen mest hadde best nytte i forhold til fallfrekvens og alvorlighetsgrad av fall. De hadde og en signifikant reduksjon i bruken av antipsykotika (12). Atferdsproblemer ble redusert og bruk av «ved behov»-medikamenter falt

\section{Sovn og sosial kontakt bedret seg i perioden da sansehagen var tilgjengelig.}

meverk som sier noe om antatte årsaker til at intervensjonen har nytteverdi.

\section{BRUK OG BETYDNING}

Bruk av sansehager kan klassifiseres som "passiv» eller "aktiv». Med «passiv bruk» menes tilstedeværelse i sansehagen med stimulering ved å nyte frisk luft, dufter, synsinntrykk, fuglesang, sol og varme. "Aktiv bruk» refererer til mer målrettete aktiviteter utført i hagen (20). etter at vandrehagen ble åpnet. Denne endringen var mer uttalt for gruppen som brukte hagen mest. Både personalet og pårørende opplevde at hagen bidro til mindre atferdsproblemer, bedre humør og økt livskvalitet (13).

Cox m.fl. (21) benyttet et sammenliknende cross over design og undersøkte nytteverdien av to typer sansemiljø; sansehage og Snoezelen-rom (et spesialinnredet multisensorisk sanserom) med opphold i sykehjemmets dagligstue. Tre ulike kognitive nivåer ble kartlagt $\mathrm{i}$ de tre ulike miljøene. Affekt ble observert, og personale og pårørende ble intervjuet om deres inntrykk av hvordan de ulike miljøene innvirket på beboerne. Forskerne rapporterer lave nivåer på negativ affekt (tristhet, sinne, angst) og høye nivåer på positiv affekt (tilfredshet) blant deltakerne generelt. Negativt affektnivå ble ikke påvirket av sansehage eller Snoezelen-rom. Derimot fant man at positivt affektnivå (glede, interesse) var høyere blant beboerne både i sansehagen og Snoezelen-rommet, sammenliknet med noe mer tristhet ved opphold i dagligstuen. Både personale og pårørende mente at sansehagen og Snoezelenrommet hadde positiv innflytelse på beboerne.

To artikler $(20,22)$ undersøkte hvordan eksisterende sansehager ble benyttet og hvordan ulike karakteristika ved hagene (utforming, tilgjengelighet, og så videre) og ved institusjonene (policy, personale og praksis) påvirket bruken av sansehagene. Grant og Wineman (22) benyttet et multicase studiedesign og kartla bruken av sansehagene («utendørsarealene») i fem sykehjem gjennom observasjoner og intervjuer med personalet. Med utgangspunkt i analyser av besøksfrekvens i hagen, form på aktivitet og bruk av hagen $\mathrm{i}$ forhold til de enkelte beboerne, identifiserte og klassifiserte forskerne en rekke faktorer som fremmet og/eller hemmet bruken av hagearealene: organisasjonens policy, personalets holdninger, visuell tilgjengelighet, fysisk tilgjengelighet og hagens utforming eller design. De fem institusjonene varierte 
betydelig med hensyn til hvordan hagene ble benyttet (passivt eller aktivt) og tilgjengelighet. I mange tilfeller bidro institusjonens policy, verdigrunnlag eller personalets holdninger til å skape hindringer. Eksempler på slike hindringer var utstrakt låsing av utgangsdøren til hagene og mangel på støtte til å komme seg ut, selv om hagene for øvrig var tilgjengelige og brukervennlige for beboerne. På bakgrunn av funnene utviklet de et kartleggingsinstrument spesielt med henblikk på å øke tilgjengeligheten og bruken av hagearealer for personer med demens.

Hernandez (20) rapporterer fra en sammenliknende case studie (to sykehjem) med utgangspunkt i deltakernes erfaringer og opplevelser, at sansehagen bidro til positive affekt og endret atferd, men at policy og praksis påvirket bruken. Det ble fremhevet at både passiv bruk (sitte ute), lav aktivitet (avledning/reduksjon av stress og agitasjon) og aktiv bruk (hageaktivitet, fysisk aktivitet, sosial aktivitet, kulturell aktivitet) av hagen hadde positiv betydning på atferd og affekt. Værforhold (høye og lave temperaturer) og begrenset adgang reduserte både nytten og utnyttelsen av hagen. Anbefalinger for å gjøre hagen mer meningsfull og nyttig for beboere og pårørende ble løftet frem.

Calkins m.fl. (24) gjennomførte en før- og etter studie med kvasieksperimentelt design i tre sykehjem, hvor de undersøkte om økt tid utendørs påvirket søvn og agitasjon. Forskerne fant at økt tid utendørs førte til moderat bedring i søvn, med varierende eller ikke målbare endringer i agitasjon. Uvanlig kaldt og vått vær om sommeren og uvanlig mildt vær om vinteren kan ha påvirket resultatene ved å redusere forskjellen mellom situasjonene som ble sammenliknet.

I en sammenliknende observasjonsstudie fra Finland undersøkte Rappe og Topo (23) hvordan det å være ute eller å kunne se ut, påvirket livskvalitet blant beboere i seks sykehjemsavdelinger og to dagsentre. Hver beboer ble observert i fire dager

\section{Sansehagen bidro til positive affekter og endret atferd.}

av to observatører og Dementia Care Mapping ble benyttet i kartleggingen. I tillegg ble det ført detaljerte feltnotater. Feltnotatene viste at det var markert forskjell mellom dagsentrene og sykehjemsavdelingene. Dagsentrene brukte utendørsaktiviteter regelmessig, i gruppe eller individuelt. Beboerne i sykehjemsavdelingene var mindre utendørs, men søkte aktivt til vinduer og/ eller balkonger som ga utsikt til livet utenfor. Begrenset tilgang til utendørsarealene var primært av praktiske grunner, som vanskelig tilgang til utearealene, mangel på personale, samt holdninger og kulturelle forhold ved institusjonene.

Mather m.fl. (25) undersøkte om en inngjerdet hage bidro til atferdsendring hos beboere med Alzheimers sykdom i en sammenliknende observasjonsstudie. Forstyrrende atferd, søvn og bruk av hagen ble observert ved tre observasjonspunkter en uke om gangen i løpet av mai (pre test), juli (mid test), september (post test). I tillegg ble beboerne observert inne både sommer og vinter. Beboerne tilbrakte 14 prosent av tiden utendørs i hagen hvor 54 prosent av tiden ute ble benyttet til å sitte og eventuelt snakke. Vandring utgjorde 26 prosent av tiden ute. Søvn og sosial kontakt bedret seg i perioden da sansehagen var tilgjengelig. Størst endringer i atferd hadde de som benyttet hagen mest. Soving om ettermiddagen, vandring og kikking ut av vinduet var hyppigere vinterstid. Det var ingen reduksjon i urolig atferd når beboerne hadde tilgang til sansehagen;

tvert imot fant de en økning i aggresjon på dagtid midt på sommeren uten at tilgang til hagen bedret situasjonen.

\section{TERAPEUTISK HAGEBRUK}

Terapeutisk hagebruk (engelsk: «therapeutic horticulture») innebærer at man bruker planter og planterelaterte aktiviteter for å fremme helse og velvære gjennom aktiv eller passiv deltakelse $(26$, s. 4). Fem studier (27-31) undersøkte nytten av terapeutisk hagebruk blant personer med demens, hvorav tre kommer fra samme forskningsgruppe (27-29). Jarrott og Gigliotti (27) anvendte et sammenliknende kontrollert design med cluster randomisering og undersøkte om hagerelaterte aktiviteter økte nivået av adaptiv atferd (definert som engasjement i aktiviteter) og positiv affekt, sammenliknet med ordinære aktiviteter. Aktivitetene var utformet for å stimulere både individenes og gruppens engasjement, med utgangspunkt i en personsentrert tilnærming. Forskerne fant signifikante forskjeller i deltakernes engasjement i fire av fem engasjementsdimensjoner $i$ 


\section{Mange av aktivitetene var for vanskelige for deltakerne, grunnet dårlig fysisk funksjon.}

TH-gruppen. TH-gruppen viste også større interesse for andre aktiviteter og hadde høyere prosentvis deltakelse enn kontrollgruppen. Kontrollgruppen var hyppigere engasjert i repeterende eller selvstimulerende aktiviteter (vandring, plukking og så videre). Det var ingen forskjeller på gruppene når det gjaldt affekt, men en signifikant sammenheng mellom alder og interesse.

Ovennevnte studie bygger videre på to tidligere studier fra de samme forskerne $(28,29)$. Forskerne (28) anvendte et sammenliknende før og etter design og undersøkte om terapeutiske hageaktiviteter en halv time per uke over ni uker påvirket nivået av engasjement og positiv affekt. Modifisert dementia mapping og atferdskategorier (sosial, hagerelatert, produktiv, ingen) ble kartlagt. Det var signifikant forskjell i gjennomsnittlig aktiv deltakelse i aktiviteter ved terapeutisk hagebruk (78 prosent), høyere engasjement og affekt, og lavere nivå av ikke-engasjement ved terapeutisk hagebruk, sammenliknet med ordinære aktiviteter (29).

I en liten svensk studie med før og etter design av Thelander m.fl. (30) på sykehjemsbeboere med moderat til alvorlig demens, kartla forskerne hvilke aktiviteter som fungerte eller ikke fungerte for den enkelte, i en parkliknende hage i nærheten av sykehjemmet. Grad av uavhengighet i gjennomføringen av aktivitetene ble også kartlagt. Forskerne rapporterer at typen aktiviteter som var mulig og tiltalende for den enkelte varierte betydelig. I gjennomsnitt varierte grad av uavhengighet mellom 2-5 på uavhengighetsskalaen, hvor lav skår indikerer uavhengighet. Mange av aktivitetene var for vanskelige for deltakerne, grunnet dårlig fysisk funksjon som ubalanse, nedsatt styrke, syns- eller persepsjonsproblemer. Halvparten trengte

\section{Pleier hjalp pasienten morgen og kveld i oppfolgingen av plantene.}

sammenliknet med ordinære aktiviteter (28 prosent). Andelen tid som «ikke engasjert», ble redusert fra 60 prosent i det ordinære aktivitetstilbudet til 14 prosent når deltakerne var engasjert $i$ terapeutiske hageaktiviteter. Forskerne fant også signifikant høyere positiv affekt ved terapeutisk hagebruk, sammenliknet med ordinære aktiviteter. De samme forskerne fant kontinuerlig hjelp, primært på grunn av fare for å falle. Beboerne utførte aktiviteter som de selv igangsatte mer uavhengig.

Connell m.fl. (31) anvendte et sammenliknende design og undersøkte nytten av et utendørs aktivitetsprogram på søvn og atferd blant sykehjemsbeboere, sammenliknet med et innendørs aktivitetsprogram. Deltakerne ble randomisert til enten et strukturert aktivitetsprogram innendørs (med terapeutisk hagebruksfokus) eller et utendørs aktivitetsprogram (dagslys og strukturerte hageaktiviteter), i grupper på fire til seks personer. Søvnstatus ble målt ti dager før oppstart og ti dager i løpet av intervensjonen (med håndleddsaktigraf med fotocelle). De målte også oppvåkning, maksimum søvnlengde, totalt søvnmengde og atferd. Utendørsgruppen hadde vesentlig mer lyspåvirkning enn innendørsgruppen, samt bedret søvn på to av tre mål. Gjennomsnittlig søvnlengde økte med en time og total søvnmengde med 50 minutter. Det var en signifikant reduksjon i verbal agitasjon. I innendørsgruppen økte total søvnmengde med 60 minutter.

\section{PLANTER INNENDøRS}

I tillegg til Connell m.fl.'s (31) studie, som ble omtalt ovenfor, har en studie av Lee og Kim (32) fra Korea undersøkt nytten av innendørs hageaktiviteter på søvn, agitasjon og kognisjon blant sykehjemsbeboere med mild til moderat demens, søvnforstyrrelser og/eller agitasjon. Innendørs hageaktiviteter med spiselige vannplanter (bønneskudd og kinesisk selleri) som intervensjon, ble valgt på grunn av gjenkjennelighet, enkelhet og rask vekst. Hver deltaker valgte en plante og dyrket og høstet denne tre til fire ganger i løpet av den fire ukers lange intervensjonen. Pleier hjalp pasientene morgen og kveld i oppfølgingen av plantene. Pasientene spiste selv grønnsakene. Nattesøvn, oppvåkning etter innsovning og soving på dagtid ble signifikant bedre. Agitasjon ble redusert og kognisjonen ble bedre. Man antar at nytten kan knyttes til 
bedret kronobiologisk rytme, $ø k t$ fysisk aktivitet, praktisering av tidligere ferdigheter, hobbyer, reminisens, sosial interaksjon, sensorisk stimulering og opplevelse av å ha utrettet noe meningsfullt.

\section{DISKUSJON}

Til tross for betydelig oppmerksomhet rundt bruken av sansehager og andre grønne miljøbehandlingstiltak, viser denne litteraturgjennomgangen at det er lite forskning på feltet. Studiene er gjennomgående små og gjennomført av et fătall forskere, primært i USA. Mangel på randomiserte kontrollerte studier (RCT) gjør det vanskelig å trekke konklusjoner om kausale sammenhenger. Til tross for betydelige forskjeller i type intervensjon og utfallsmål, tyder de fleste studiene på at sansehager, vandrehager og terapeutisk hagebruk ute og inne kan ha en positiv innvirkning. I motsetning til andre miljøbehandlingsformer, hvor hovedfokus gjerne er på atferdsproblematikk (10), viser disse studiene et bredere spekter av utfallsmål ofte med fokus på økt trivsel, engasjement og aktivitet. Terapeutisk hagebruk, både ute og inne, ser ut til å bidra til bedret søvn, økt engasjement og trivsel. "Passiv» bruk av sansehager er forbundet med bedret søvn, færre alvorlige fall, nedsatt bruk av psykofarmaka samt økt trivsel og livskvalitet. Litteraturgjennomgangen antyder at individualisering er viktig ved bruk av sansehage og terapeutisk hagebruk, både fordi den enkeltes kognitive funksjon og fysiske helse varierer betydelig og fordi interesser og ferdigheter er forskjellige.

Studiene viser at det er stor variasjon i utforming og tilgang til sansehager. Det er påfallende at flere av studiene viser at institusjonens policy, personalets holdninger og mangel på støtte reduserer bruken av sansehager, også når de for øvrig er fysisk godt tilrettelagt for personer med demens. Videre fant flere av mobile å få tilgang til sansehagen. Det anbefales også aktiv støtte av individualisert bruk, samt tilrettelegging for tilpassete gruppeaktiviteter. Betydningen av en utforming som gir skyggemuligheter, le for vinden $o g$ attraktive områder

\section{Det er stor variasjon i utforming og tilgang til sansehager.}

studiene at sansehagene hadde begrenset anvendelse store deler av året, grunnet for høye eller lave temperaturer. Manglende skjerming for sol, regn og vind ble påpekt i flere av casestudiene. Manglende opplæring og støtte til å bruke sansehager og terapeutisk hagebruk blant personalet synes å være en viktig faktor som reduserer bruken av denne miljøbehandlingsformen. Opplæring synes å bidra til økt bruk og til at hagearealene $\mathrm{i}$ sykehjem legges bedre til rette for personer med demens (33).

Litteraturgjennomgangen dokumenterer tydelig behovet for mer forskning på bruk av sansehager og terapeutisk hagebruk for personer med demens. Kunnskapsgrunnlaget på dette feltet er begrenset, men lovende. Særlig trengs det mer kunnskap om hvordan sansehager faktisk benyttes, hvilke faktorer som fremmer og hemmer målrettet bruk av sansehager og terapeutisk hagebruk, samt større, kontrollerte studier som undersøker effekten av denne typen miljøbehandling for funksjon, helse og trivsel hos personer med demens. Eksisterende forskning understreker betydningen av at personalet legger til rette for bruk av sansehager gjennom å fjerne hindringer som gjør det vanskelig for pasienter som er for å gå og sitte understrekes også. Litteraturen viser videre at nærliggende parker kan benyttes aktivt som sansehager eller arena for terapeutisk hagebruk. Økt kunnskap og opplæring synes nødvendig for å støtte personalet i bruk av denne formen for miljøbehandling. Litteraturen understreker også betydningen av å kunne utnytte elementer fra sansehager og terapeutisk hagebruk innendørs, noe som synes svært viktig i Norge, med sine lange vintre og korte sommersesong.

\section{KONKLUSJON}

Forskning om bruken og betydningen av «grønn miljøbehandling» $i$ omsorgen for personer med demens er begrenset. Tilgjengelig forskningslitteratur antyder at sansehage og terapeutisk hagebruk ute og/eller inne kan ha en positiv betydning for personer med demens. Mer systematisk forskning, inklusive studier med randomisert kontrollert design og større utvalg, er nødvendig for å øke kunnskapsgrunnlaget.

Arbeidet med denne artikkelen ble giennomfort med finansiering fra Demensfyrtarnprosjektet og $i$ samarbeid med Utviklingssenter for sykehjem $i$ Oslo. 


\section{REFERANSER}

1. Engedal K, Haugen PK. Demens. Fakta og utfordringer. Tønsberg: Aldring og helse; 2005

2. Berentsen VD. Kognitiv svikt og demens. I: Kirkevold M, Brodtkorb K, Ranhoff AH, editors. Geriatrisk sykepleie. God omsorg til den gamle pasienten. Oslo: Gyldendal Akademisk; 2008. s. $350-82$.

3. Statens beretning för medicinsk utvärdering. Demenssykdommer. En systematisk litteraturoversikt. Tønsberg: 2006

4. Sosial-og Helsedirektoratet. Glemsk, men ikke glemt! Om dagens situasjon og framtidas utfordringer for å styrke tjenestetilbudet til personer med demens. Oslo: 2007

5. Rokstad AMM. Hva er demens? I: Rokstad AMM, Smebye KL. (red). Personer med demens. Møte og samhandling. Oslo: Akribe; 2008; 27-45.

6. Rokstad AMM. Utfordrende atferd. I: Rokstad AMM, Smebye KL. (red). Personer med demens. Møte og samhandling. Oslo: Akribe; 2008;180-206.

7. Rokstad AMM. Miljøbehandling. I: Rokstad AMM, Smebye KL. (red). Personer med demens. Møte og samhandling. Oslo: Akribe; 2008;152-79.

8. Vatne S. Korrigere og anerkjenne: relasjonens betydning i miljøterapi. Oslo: Gyldendal akademisk; 2006. 216 s.

9. Wogn-Henriksen K. Miljøbehandling i demensomsorgen. In: Krüger RME, $\emptyset$ vereng $A$, editors. Det går an! Muligheter i miljøterapi. Tønsberg: Aldring og helse, 2007: 18-35.

10. Lee A. Pleje- og omsorgsmetoder til demensramte. En litteraturstudie af den dokumenterede effekt. Odense: Styrelsen for social service - CAST - Center for anvendt sundhedstjenesteforskning og teknologivurdering, 2004.

11. Murphy PF, Miyazaki Y, Detweiler MB, Kim KY. Longitudinal analysis of differential effects on agitation of a therapeutic wander garden for dementia patients based on ambulation ability. Dementia. 2010;9:355-73.

12. Detweiler MB, Murphy PF, Kim KY, Myers LC, Ashai A. Scheduled medications and falls in dementia patients utilizing a wander garden. American Journal of Alzheimers Disease and Other Dementias. 2009;24:322-32.

13. Detweiler MB, Murphy PF, Myers LC, Kim KY. Does a wander garden influence inappropriate behaviors in dementia residents. American Journal of Alzheimers Disease and Other Dementias. 2008:23:31-45.

14. Milligan C, Gatrell A, Bingley A. «Cultivating health»: therapeutic landscapes and older people in northern England. Social Science \& Medicine. 2004:1781-93.

15. Detweiler MB, Warf C. Dementia wander garden aids post cerebrovascular stroke restorative therapy: a case study. Alternative Therapies in Health and Medicine. 2005;11: 54-8.

16. Haas K, Simson SP, Stevenson NC. Older persons and horticultural theory practice. I: Simson SP, Straus MC. (red). Horticulture as therapy. Principles and practice. New York: The Food Product Press; 1995;231-56.

17. Mays N, Roberts E, Popay J. Synthesizing research evidence. I: Fulop P, Allen AC, Black N.(red). Studying the organisation and delivery of health services: Research Methods. London: Routledge; 2001; 188-220.

18. Arksey H, O>Malley L. Scoping studies: towards a methodological framework. International Journal of Social Research Methodology. 2005;8:19-32.

19. Davis K, Drey N, Geould D. What are scoping studies? A review of the nursing literature International Journal of Nursing Studies. 2009;46:1386-400.

20. Hernandez RO. Effects of therapeutic gardens in special care units for people with dementia: two case studies. Journal of Housing for the Elderly. 2007;21:11752.

21. Cox H, Burns I, Savage S. Multisensory environments for leisure: promoting well-being in nursing home residents with dementia. Journal of gerontological nursing. 2004;30: 37-45.

22. Grant CF, Wineman JD. The GardenUse-Model - An environmental tool for increasing the use of outdoor space by residents with dementia in long-term care facilities. Journal of Housing for the Elderly. 2007;21:89-115.

23. Rappe E, Topo P. Contact with outdoor greenery can support competence among people with dementia. Journal of Housing For the Elderly. 2007;21:229-48.

24. Calkins M, Szmerekovsky JG, Biddle S. Effect of increased time spent outdoors on individuals with dementia residing in nursing homes. Journal of Housing For the Elderly. 2007;21:211-28.

25. Mather JA, Nemecek D, Oliver KO. The effect of a walled garden on behavior of individuals with Alzheimerss. American Journal of Alzheimers Disease and
Other Dementias. 1997:12:252-57.

26. GrowthPoint. Your future starts here: practitioners determine the way ahead. 1999:79:4-5

27. Jarrott SE, Gigliotti CM. Comparing responses to horticultural-based and traditional activities in dementia care programs. American Journal of Alzheimers Disease and Other Dementias. 2010;25:657-65

28. Gigliotti CM, Jarrott SE. Effects of horticulture therapy on engagement and affect. Canadian Journal on AgingRevue Canadienne Du Vieillissement 2005;24:367-77.

29. Gigliotti C, Jarrott S, Yorgason J. Harvesting health: effects of three types of horticultural therapy activities for persons with dementia Dementia. 2004:3:161-80

30. Thelander VB, Wahlin TR, Olofsson L, Heikkila K, Sonde L. Gardening activities for nursing home residents with dementia. Advances in Physiotherapy. 2008;10:53-6.

31. Connell BR, Sanford JA, Lewis D. Therapeutic effects of an outdoor activity program on nursing home residents with dementia. Journal of Housing for the Elderly. 2007;21:195-209.

32. Lee Y, Kim S. Effects of indoor gardening on sleep, agitation, and cognition in dementia patients - a pilot study. International Journal of Geriatric Psychiatry. 2008:23:485-9.

33. Chapman NJ, Hazen T, NoellWaggoner E. Gardens for people with dementia: increasing access to the natural environment for residents with Alzheimerss. Jornal of Housing for the Elderly. 2007;21:249-63.

Les kommentaren på side 65 >> 